UDC 629.463.027.23

\author{
O. A. SHYKUNOV ${ }^{1 *}$ \\ ${ }^{1 *}$ Dep. «Cars and Cars Facilities», Dnipropetrovsk National University of Railway Transport named \\ after Academician V. Lazaryan, Lazaryan St., 2, Dnipro, Ukraine, 49010, tel. +38 (056) 3731504 , \\ e-mail tri_s@ua.fm, ORCID 0000-0002-8256-2634
}

\title{
THREE-ELEMENT BOGIE SIDE FRAME STRENGTH
}

Purpose. To evaluate the effect of different loads on the stress-strain state of the freight car bogie side frame, as well as to evaluate the distribution of the stress fields in the design of the freight car bogie side frame supported through the horizontal surface and through the horizontal and inclined surfaces of the pedestal opening. Methodology. A volumetric finite element model of the side frame of ZK-1 bogie of the freight car was designed. The forces under the current regulatory documentation for theoretical research were applied to the model, the stress arising in the model elements were determined. The static tests of ZK-1 bogie side frame were conducted; they allowed determining the stresses in the key points of the frame under the action of forces in accordance with the existing procedure of static tests of the freight car bogie side frame. To check the quality of the finite element model we determined the stress in the model under the action of forces corresponding to the static requirements. The corresponding coefficients were determined to match the stress obtained through theoretical studies and static tests. The results of theoretical and experimental studies of stress for dangerous sections of the side frame design were compared. Findings. The regulatory documentation for carrying out experimental research of the side frame strength does not fully take into account the load acting on the frame during its operation and that provided while assessing the side frame strength theoretically. The strength evaluation of the side frame by the results of field tests only does not give a complete picture of the distribution of stress fields, as the provided sensor installation points do not cover most of the design elements with possible stress concentration. Originality. The loads applied to the side frame during theoretical and experimental studies were compared to the loads acting during operation. The impact of use of inclined surfaces in the pedestal box opening was evaluated. Practical value. The obtained results allow the more accurate assessment of the three-piece bogie side frame strength, as well as allow you to choose the more preferred method of side frame support in the axle box.

Keywords: side frame; three-piece bogie; strength; test; calculation; support

\section{Introduction}

The strength of new and upgraded designs of car elements is assessed using the experimental and theoretical studies. Each car element must pass these two stages, and for each of them there are developed regulations governing the load to be applied to the object during theoretical and experimental studies $[3,7,8,10]$.

For freight car three-piece bogie side frame such documents are «Regulations for calculation and design of cars of $1520 \mathrm{~mm}$ gauge railways of Ministry of Railways (non-self-propelled)» [8] for theoretical studies and «Bolsters and cast side frames of four-wheel bogie of freight cars for 1520 $\mathrm{mm}$ track. Methods of static strength tests» [7] for the experimental ones.

However, the loads under which the stressstrain state of the side frame is studied during theoretical and experimental studies differ in both value and place of application. And if the difference between the values of the existing loads can be compensated by appropriate co-coefficients, it is much more complicated to compensate the difference in places of load application, which leads to difficulties in comparing the results of experimental and theoretical studies.

Development of Ukrzaliznytsia rolling stock and that of the CIS countries in recent years is aimed at increasing the efficiency of cars, not only due to speeding up [6], but also due to their higher carrying capacity by increasing the axle load from 23.5 ton/axle to 25 tons/axle [ $4,5,13,18]$.

Increased weight of transported cargo results in the need to strengthen the construction of the car body and undercarriage [1]. At the same time, the increase in car gross mass, along with the constant influence of static load, constantly acting on the bogie from the side of body and cargo, results in increased dynamic component, which occurs during car movement on the main tracks. That leads to the need for additional structural reinforcement of 
the bogie and its side frame as one of the elements [11].

An alternative to increased strength of bogie components is reduced dynamic effects on the bogie during movement. This effect is achieved in various ways, such as: the use of a bilinear spring suspension at the central core stage, the improvement of friction pairs in the friction wedge-type shock absorber, installation of additional connections between the bogie side frames, etc. $[2,12,15,16,17]$.

One of the ways to reduce the dynamic component of the load acting on the side frame is to install the second suspension stage between bogie side frame and the wheelset axle box. This assembly is set with an elastic spring element, polyurethane, rubber or rubber-metal gasket. This element can receive and transmit further both exclusively vertical forces and vertical and horizontal forces.

If to take up the first ones, the horizontal support surfaces in the pedestal opening of the bogie side frame are enough, then to transmit the horizontal forces, it is necessary to provide for the presence of the elastic element between the vertical support surfaces. Realizing such a support way it is necessary to prevent from elastic element falling out of the space between the vertical support surfaces, by means of its additional fastening, which leads to complicated construction in the place of interaction of side frame and axle box. An alternative is to set the elastic elements on inclined surfaces for taking up the vertical and horizontal loads by one and the same elastic element. For this purpose, it is necessary to provide for appropriate support surfaces both of the axle box housing and in the pedestal opening or to use adapters. The second way is not effective, although it leads to increased side frame unification, but the presence of additional elements results in reduced work space in the pedestal opening and sizes of the elastic gasket.

The transition from boxes to the cassette type bearings and the axle box adapters allows abandoning the unified box housing and applying axle box adapters with different surfaces for side frame supporting.

The need for inclined support surfaces in the pedestal opening also involves changes in the bogie side frame, and transfer of the horizontal loads or most of them through the upper member of the pedestal opening leads to the redistribution of stresses in the side frame and the need of strengthening in the places not critical for frames with separate load transfer.

\section{Purpose}

The purpose of the work is to evaluate the effect of different loads on the stress-strain state of the freight car bogie side frame, as well as to evaluate the distribution of the stress fields in the design of the freight car bogie side frame supported through the horizontal surface and through the horizontal and inclined surfaces of the pedestal opening.

\section{Methodology}

The study was conducted for the side frame of the three-piece bogie of ZK-1 model made in China.

ZK-1 bogie side frame has the construction typical for three-piece bogie side frames - it consists of upper, lower, diagonal members and 2 columns. Support on wheelsets is through pedestal openings, the upper surface of which is 2-pitch with a horizontal platform in the middle. The central opening of the side frame houses a set of 9 2-row suspension springs. The friction shock absorber plates are mounted on the inner surface.

To evaluate the stress-strain state of the side frame the finite element model is developed. There are applied solid 10-unit elements with a characteristic edge size of $10 \mathrm{~mm}$. Dimensions of the elements vary in model volume and decrease in the places of openings, radius transitions and other potential stress raisers. The element size is chosen so that its further change would have no effect on the calculation results. The modelling process first created the three-dimensional geometrical model (Fig. 1), which was automatically divided into three-dimensional finite elements (Fig. 2). The resulting finite element model of the bogie has 664,705 elements, $1,789,864$ units and 5,369,592 degrees of freedom.

For model material, the following values of the elastic constants of the material are assumed: Young's modulus $E=210 \mathrm{GPa}$, Poisson's ratio $v=0.27$.

The calculation was performed in accordance with the «Regulations...» [8], which state that the bogie side frame is subjected to the combination of vertical, side and longitudinal loads. 


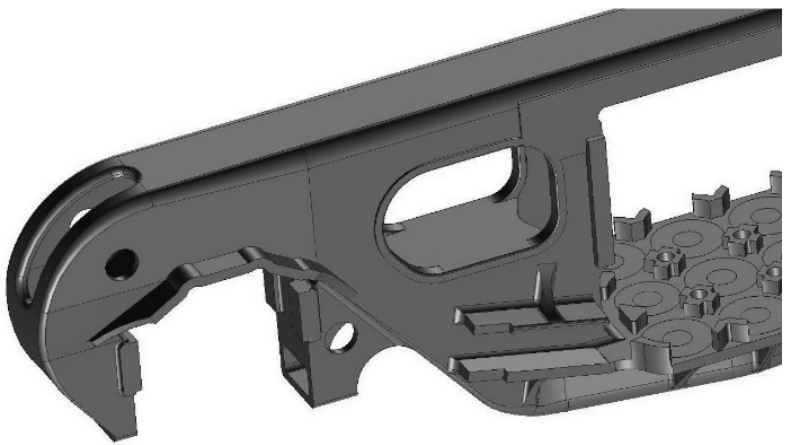

Fig. 1. Geometric model of ZK-1 bogie side frame

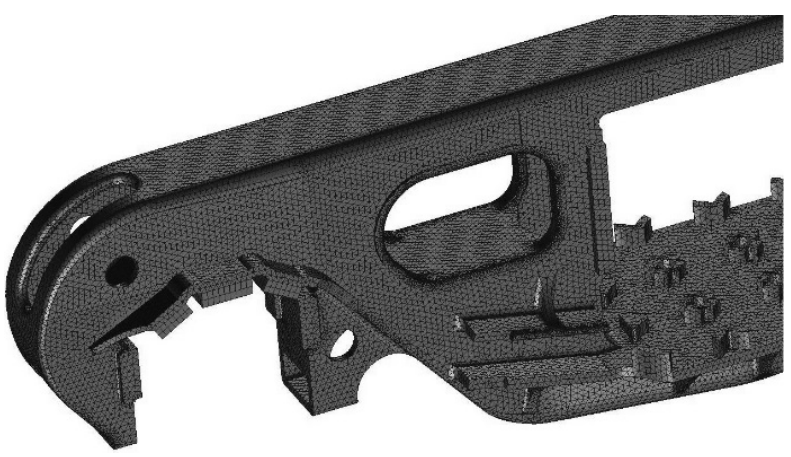

Fig. 2. Detail of the finite element model of ZK-1 bogie side frame

Vertical loads are as follows:

- Vertical static load,

- Vertical dynamic load,

- Vertical contribution of longitudinal inertia force of the car,

- Vertical contribution of braking force,

- Vertical contribution of forces of inertia in the curve and wind pressure strength.

Side loads are as follows:

- Wind pressure forces and centrifugal force during the passage curved track sections,

- Transverse component of longitudinal quasistatic force,

- Frame force.

Longitudinal loads are as follows:

- Bogie mass inertia force,

- Brake force,

- Thrust force of friction wedges.

These loads are grouped in six variants of loading that correspond to:

a) the forces acting on the car during its collision with the train when breaking-up from a hump;

b) the forces acting on the car in the middle of the train with braked front cars and not braked, approaching from the rear cars; c) the forces acting on the last car moving with the design speed in the train during adjusting braking at the beginning of the curved section;

d) the forces acting on the last car moving with the design speed in the train during adjusting braking at the straight track section;

e) the forces acting on the car moving with the design speed in the train during adjusting braking in a curve, with braked front cars and not braked, approaching from the rear cars;

f) the forces acting on the car moving with the design speed in the train during adjusting braking in a curve.

The I design mode corresponds to the variants of loading $a$ and $b$, III $-c \ldots f$.

Table 1 shows the values and points of origin of the maximum stress in the bogie side frame.

Table 1

The maximum stresses in the bogie side frame, MPa

\begin{tabular}{|c|c|c|c|}
\hline $\begin{array}{l}\text { Variant } \\
\text { of load- } \\
\text { ing }\end{array}$ & Point of origin & $\begin{array}{c}\text { Limit } \\
\text { values }\end{array}$ & $\begin{array}{c}\text { Calculated } \\
\text { value }\end{array}$ \\
\hline $\mathrm{a}$ & $\begin{array}{l}\text { Lower angles of the } \\
\text { central spring open- } \\
\text { ing }\end{array}$ & 250 & 240 \\
\hline $\mathrm{b}$ & $\begin{array}{l}\text { Vertical support } \\
\text { surface of the pedes- } \\
\text { tal opening }\end{array}$ & 250 & 235 \\
\hline $\mathrm{c}$ & $\begin{array}{l}\text { Lower angles of the } \\
\text { central spring open- } \\
\text { ing }\end{array}$ & 140 & 132 \\
\hline d & $\begin{array}{l}\text { Vertical support } \\
\text { surface of the pedes- } \\
\text { tal opening }\end{array}$ & 140 & 137 \\
\hline e & $\begin{array}{l}\text { Vertical support } \\
\text { surface of the pedes- } \\
\text { tal opening }\end{array}$ & 140 & 139 \\
\hline$f$ & $\begin{array}{l}\text { Lower angles of the } \\
\text { central spring open- } \\
\text { ing }\end{array}$ & 140 & 131 \\
\hline
\end{tabular}

This side frame also underwent the complex of static strength tests according to [7]. Tests were carried out on the territory of Qiqihar Railway Rolling Stock Co. Ltd. (PRC) on the testing machine ZDM 200Pu.

During the tests, the stresses occurring at the control points of the side frame due to five loading 
schemes were registered. For the side frames of the cars with $245 \mathrm{kN}$ axle load there are the following values of the test loads and the places of their application:

1 - vertical load of $490 \mathrm{kN}$ uniformly applied to support places of the central group springs;

2 - horizontal load of $147 \mathrm{kN}$ applied on the outer side of the frame to one of the columns of the central spring opening;

3 - horizontal loads of $73.5 \mathrm{kN}$ each applied on the outer side of the frame to both columns of the central spring opening;

4 - horizontal loads of $122 \mathrm{kN}$ each applied to the friction plates of the central spring opening;

5 - horizontal loads of $66 \mathrm{kN}$ each applied to the vertical surfaces of the pedestal opening.

To check the adequacy of the finite element model of the real side frame, the calculations were conducted, in which the finite element model was subjected to the loads similar to the experimental ones, and the calculation resulting stresses were compared with those obtained during the tests [14]. Figure 3 shows the control sections and the sensor installation location during the test.

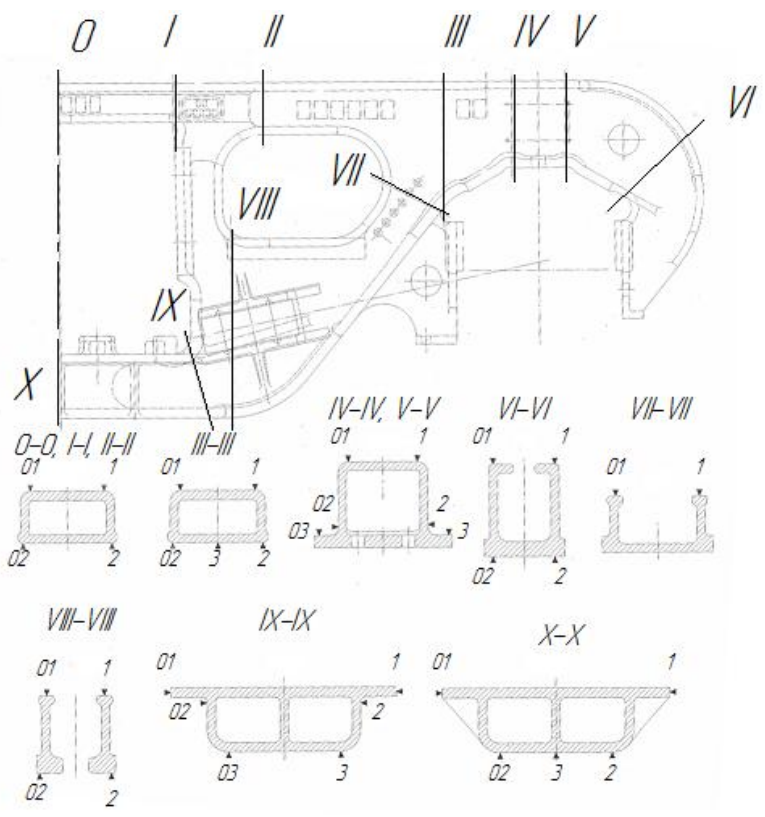

Fig. 3. Layout of strain sensors for static tests

Comparison of calculation and test results for some check points is given in Table 2 .

As can be seen from Table 2 the results of theoretical studies are in good agreement with the test results, indicating the adequacy of the finite element model and the real side frame.
To compare the results of theoretical studies according to the «Regulations...» [8] and the experiment according to the method [7], there were calculated the correlation coefficients of the loads applied during testing and load combinations that act on the side frame according to the «Regulations...». These coefficients are presented in Table 3.

Table 2

\section{Stresses in check points during testing and theoretical modelling}

\begin{tabular}{|c|c|c|}
\hline \multirow{2}{*}{ Section-point } & \multicolumn{2}{|c|}{ Stresses during loading by scheme, $\mathrm{MPa}$} \\
\hline & 1 & 2 \\
\hline \multirow{2}{*}{$0-2$} & -54.23 & -42.73 \\
\hline & -47.73 & -44.46 \\
\hline \multirow{2}{*}{$0-02$} & -48.10 & 44.83 \\
\hline & -49.80 & 40.66 \\
\hline \multirow{2}{*}{$\mathrm{I}-2$} & -81.83 & -99.67 \\
\hline & -86.59 & -125.93 \\
\hline \multirow{2}{*}{ I'-2 } & -73.80 & -43.03 \\
\hline & -97.82 & -59.88 \\
\hline \multirow{2}{*}{ III-2 } & 94.23 & -0.57 \\
\hline & 108.34 & 23.34 \\
\hline \multirow{2}{*}{ III'-2 } & 68.43 & -15.47 \\
\hline & 109.69 & 16.40 \\
\hline \multirow{2}{*}{ III'-02 } & 93.00 & 8.23 \\
\hline & 115.24 & -16.99 \\
\hline \multirow{2}{*}{ VIII'-1 } & -72.30 & -10.70 \\
\hline & -70.25 & -14.47 \\
\hline \multirow{2}{*}{ IX-1 } & 31.50 & -164.40 \\
\hline & 44.59 & -112.94 \\
\hline \multirow{2}{*}{ IX-01 } & 22.23 & 103.60 \\
\hline & 67.82 & 165.31 \\
\hline \multirow{2}{*}{$\mathrm{X}-02$} & 100.10 & 17.87 \\
\hline & 105.53 & 15.69 \\
\hline
\end{tabular}




\begin{tabular}{|c|c|c|c|}
\hline \multicolumn{4}{|c|}{ End of table } \\
\hline \multirow{2}{*}{$\begin{array}{l}\text { Section- } \\
\text { point }\end{array}$} & \multicolumn{3}{|c|}{ Stresses during loading by scheme, $\mathrm{MPa}$} \\
\hline & 3 & 4 & 5 \\
\hline \multirow{2}{*}{$0-2$} & -41.13 & -22.17 & -0.30 \\
\hline & -26.13 & -21.26 & -0.60 \\
\hline \multirow{2}{*}{$0-02$} & 38.7 & 21.83 & -0.70 \\
\hline & 23.82 & 19.79 & -0.53 \\
\hline \multirow{2}{*}{$\mathrm{I}-2$} & -57.50 & 24.83 & -3.23 \\
\hline & -53.00 & 30.29 & -2.61 \\
\hline \multirow{2}{*}{ I'-2 } & -67.77 & 21.90 & 0.60 \\
\hline & -61.66 & 35.38 & 0.74 \\
\hline \multirow{2}{*}{ III-2 } & -8.50 & -3.37 & 23.40 \\
\hline & 11.85 & -4.50 & 24.81 \\
\hline \multirow{2}{*}{ III'-2 } & -11.43 & -2.47 & 0.07 \\
\hline & 11.94 & -4.63 & 0.01 \\
\hline \multirow{2}{*}{ III'-02 } & 3.73 & -3.23 & 0.10 \\
\hline & -12.52 & -4.46 & 0.01 \\
\hline \multirow{2}{*}{ VIII'-1 } & -20.67 & -30.00 & 0.03 \\
\hline & -18.41 & -29.97 & 0.06 \\
\hline \multirow{2}{*}{ IX-1 } & -132.20 & 9.23 & -0.73 \\
\hline & -54.39 & 11.05 & -0.87 \\
\hline \multirow{2}{*}{ IX-01 } & 84.83 & 11.53 & -0.97 \\
\hline & 84.93 & 11.07 & -1.00 \\
\hline \multirow{2}{*}{$\mathrm{X}-02$} & 17.10 & -0.70 & -0.13 \\
\hline & 9.42 & -1.33 & 0.14 \\
\hline
\end{tabular}

Table 4 shows the stresses obtained at the check points during the theoretical study of stress-strain state of the side frame according to the «Regulations...» (denominator) and the ones resulting from conversion of the test results, taking into account the coefficients of Table 3 (numerator).

Table 3

Load ratio during theoretical and experimental studies of the side frame

\begin{tabular}{l|c|c|c|c}
\hline \multirow{2}{*}{$\begin{array}{c}\text { Variant } \\
\text { of load- } \\
\text { ing }\end{array}$} & $\begin{array}{c}\text { Vertical } \\
\text { stress on } \\
\text { lower } \\
\text { member }\end{array}$ & $\begin{array}{c}\text { Trans- } \\
\text { verse } \\
\text { force on } \\
\text { columns }\end{array}$ & $\begin{array}{c}\text { Thrust } \\
\text { force of } \\
\text { wedges }\end{array}$ & $\begin{array}{c}\text { Longitu- } \\
\text { dinal } \\
\text { stress }\end{array}$ \\
\hline $\mathrm{a}$ & 0.91 & 0 & 0.36 & 1.24 \\
$\mathrm{~b}$ & 0.46 & 1.44 & 0.21 & 0.89 \\
$\mathrm{c}$ & 0.89 & 0.23 & 0.35 & 0.35 \\
$\mathrm{~d}$ & 0.77 & 0.81 & 0.31 & 0.74 \\
$\mathrm{e}$ & 0.80 & 0.81 & 0.32 & 0.74 \\
$\mathrm{f}$ & 0.80 & 0.81 & 0.32 & 0 \\
& & & & Table 4
\end{tabular}

Stresses in check points during theoretical modelling and test result conversion

\begin{tabular}{l|c|c|c}
\hline \multirow{2}{*}{$\begin{array}{c}\text { Section- } \\
\text { point }\end{array}$} & \multicolumn{3}{|c}{ Stresses during loading by scheme, MPa } \\
\cline { 2 - 4 } & $\mathrm{a}$ & $\mathrm{b}$ & $\mathrm{c}$ \\
\hline 1 & 2 & 3 & 4 \\
\hline \multirow{2}{*}{$0-2$} & -42.00 & -80.01 & -50.19 \\
& -31.04 & -53.26 & -40.06 \\
$0-02$ & -37.02 & 37.47 & -26.49 \\
& -33.53 & 20.26 & -30.40 \\
I-2 & -69.88 & -118.44 & -78.66 \\
& -69.82 & -114.42 & -80.50 \\
I'-2 & -58.84 & -126.75 & -73.56 \\
& -62.40 & -120.37 & -86.33 \\
III-2 & 113.84 & 51.46 & 89.01 \\
& 59.87 & 18.25 & 83.99 \\
III'-2 & 61.67 & 14.80 & 57.41 \\
& 96.42 & 42.74 & 95.40 \\
III'-02 & 83.87 & 47.91 & 82.54 \\
& 101.50 & 60.87 & 102.22 \\
& & &
\end{tabular}

Note: The numerator shows the values obtained from the tests, the denominator - those from theoretical studies.

The use of the coefficients shown in Table 3 allows converting the stresses obtained during the static test to compare them with the results of theoretical studies by the formula:

$$
\sigma_{i}=\sum k_{i j} \sigma_{j}
$$

where $\sigma_{i}$ - stresses obtained during the static tests by the $j$-th loading scheme, MPa; $k_{i j}$ - coefficient taking into account the ratio of the forces applied by the $j$-th loading scheme of the static tests and the $i$ th variant of loading of the theoretical studies; $i$ variant of loading during theoretical studies, $i=1,2$, $\ldots, 6 ; j$ - loading scheme for static tests, $j=1,3,4,5$. 


\begin{tabular}{|c|c|c|c|c|}
\hline \multicolumn{4}{|c|}{ Continuation table 4} & \multirow{2}{*}{$\begin{array}{l}\text { Note: The numerator shows the values obtained } \\
\text { from conversion of the test results, the denominator - } \\
\text { the results of theoretical studies. }\end{array}$} \\
\hline \multirow{2}{*}{$\begin{array}{l}\text { Section- } \\
\text { point }\end{array}$} & \multicolumn{3}{|c|}{ Stresses during loading by scheme, MPa } & \\
\hline & $\mathrm{a}$ & $\mathrm{b}$ & $\mathrm{c}$ & \\
\hline 1 & 2 & 3 & 4 & $\begin{array}{l}\text { As can be seen from Table } 4 \text { between the re- } \\
\text { sults of theoretical studies and the converted re- }\end{array}$ \\
\hline \multirow{2}{*}{ VIII'-1 } & -76.62 & -69.63 & -79.56 & sults of the experiment there is the large enough, \\
\hline & -65.16 & -57.51 & -68.07 & sometimes more than $100 \%$, discrepancy. For ex- \\
\hline \multirow{2}{*}{ IX-1 } & 31.13 & -174.64 & 0.33 & $\begin{array}{l}\text { ample, at III- } 2 \text { section for the variants of loading } a \\
\text { and } b \text { the experimental-converted stresses exceed }\end{array}$ \\
\hline & 45.69 & -78.17 & -33.83 & the theoretical ones by 1.9 and 2.8 times, while for \\
\hline \multirow{2}{*}{ IX-01 } & 23.18 & 134.16 & 43.12 & the variant of loading $c$ they are almost equal. For \\
\hline & 68.29 & 161.82 & 85.80 & to the vertical transverse plane, under the same \\
\hline \multirow{3}{*}{$\mathrm{X}-02$} & 55.45 & 10.85 & 51.24 & variants of loading the experimental-converted \\
\hline & 90.45 & 30.18 & 86.21 & $\begin{array}{l}\text { stresses are } 1.5 \text { and } 2.9 \text { times below the theoretical } \\
\text { ones. At the same time there are no significant dif- }\end{array}$ \\
\hline & \multicolumn{3}{|c|}{ End of table 4} & ferences between the sections under the action of \\
\hline \multirow{2}{*}{$\begin{array}{l}\text { Section- } \\
\text { point }\end{array}$} & \multicolumn{3}{|c|}{ Stresses during loading by scheme, MPa } & e Table \\
\hline & $\mathrm{d}$ & $\mathrm{e}$ & $\mathrm{f}$ & ing $a$ and $b$ correspond to the I-calculation mode \\
\hline 1 & 5 & 6 & 7 & and the longitudinal load, taken into account in \\
\hline \multirow{2}{*}{$0-2$} & -68.25 & -69.66 & -69.43 & theoretical studies, is high enough for these vari- \\
\hline & -49.19 & -50.80 & -53.78 & ants. Simulation of action of bogie mass inertia \\
\hline \multirow{2}{*}{$0-02$} & 0.73 & -0.63 & -0.11 & When these forces are applied to one of the friction \\
\hline & -9.32 & -11.05 & -13.98 & plate surfaces, the side frame thrusts against one \\
\hline \multirow{2}{*}{$\mathrm{I}-2$} & -104.01 & -106.25 & -103.85 & $\begin{array}{l}\text { pedestal opening with its inner vertical surface, } \\
\text { while with its external surface in the other opening }\end{array}$ \\
\hline & -103.14 & -106.17 & -105.69 & [9]. This causes not symmetrical loading of the \\
\hline \multirow{2}{*}{ I'-2 } & -104.24 & -106.24 & -106.68 & side frame and leads to redistribution of stresses in \\
\hline & -108.12 & -111.52 & -120.42 & $\begin{array}{l}\text { the structure. It is not correct to replace the action } \\
\text { of these forces with the test results when subjected }\end{array}$ \\
\hline \multirow{2}{*}{ III-2 } & 81.60 & 84.65 & 67.29 & to thrust loads in the central and the pedestal open- \\
\hline & 57.22 & 61.55 & 84.53 & ing, since during such loadings the side frame sec- \\
\hline \multirow{2}{*}{ III'-2 } & 42.44 & 44.66 & 44.61 & $\begin{array}{l}\text { tion between the column and the pedestal opening } \\
\text { practically does not work because there is no ten- }\end{array}$ \\
\hline & 79.68 & 84.08 & 85.56 & sile or compressive load on it. \\
\hline \multirow{2}{*}{ III'-02 } & 73.32 & 76.31 & 76.24 & Also, the stress field distribution analysis revealed \\
\hline & 90.36 & 94.96 & 96.52 & given in [7] even though located in the most loaded \\
\hline \multirow{2}{*}{ VIII'-1 } & -81.34 & -84.05 & -84.08 & sections, however, they often do not provide a com- \\
\hline & -68.11 & -71.04 & -73.77 & plete picture of the maximum stress values arising in \\
\hline \multirow{2}{*}{ IX-1 } & -80.70 & -79.30 & -78.76 & $\begin{array}{l}\text { these sections. Ine stresses occurring in the check } \\
\text { section or near it may exceed two or more times the }\end{array}$ \\
\hline & -42.58 & -42.47 & -41.59 & value at the sensor location point (Fig. 4). \\
\hline \multirow{2}{*}{ IX-01 } & 88.60 & 89.31 & 90.03 & $\begin{array}{l}\text { To compare the stress distribution in the side } \\
\text { frames with different support in axle box openings, }\end{array}$ \\
\hline & 127.45 & 130.21 & 129.57 & we modelled also the side frame supported in axle \\
\hline \multirow{2}{*}{$\mathrm{X}-02$} & 36.77 & 38.78 & 38.76 & box only through the horizontal surfaces similar to \\
\hline & 67.41 & 71.53 & 71.88 & \\
\hline
\end{tabular}




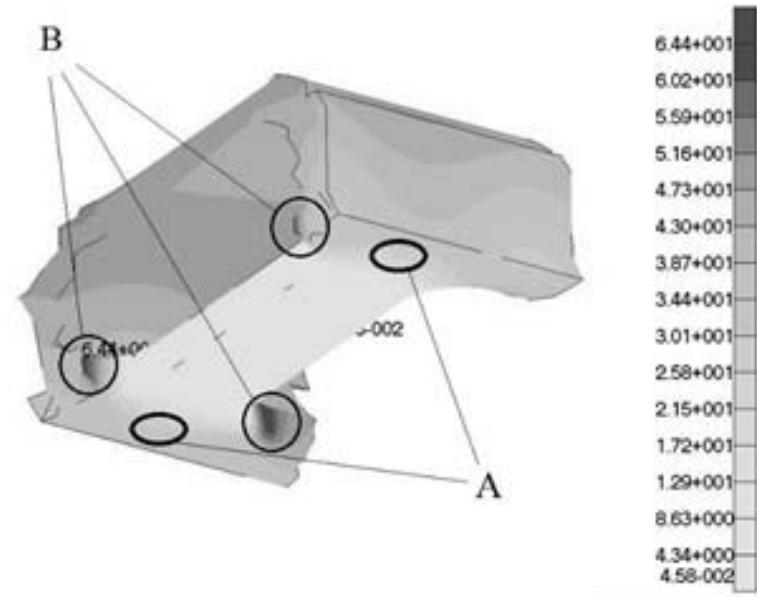

Fig. 4. Stress distribution in the cross section 0 on the side frame upper member:

$A$ - sensor installation location $(\sim 34.4 \mathrm{MPa})$; $B$ - areas with high stress $(64.4 \mathrm{MPa})$

Besides, the volume model was created for this side frame; it is shown in Figure 4, as well as the finite element model (Fig. 5). The solid 10-unit elements with a characteristic edge size of $10 \mathrm{~mm}$ were used. The resulting finite element model of the bogie has 812,400 elements $1,290,310$ units and $3,870,930$ degrees of freedom.

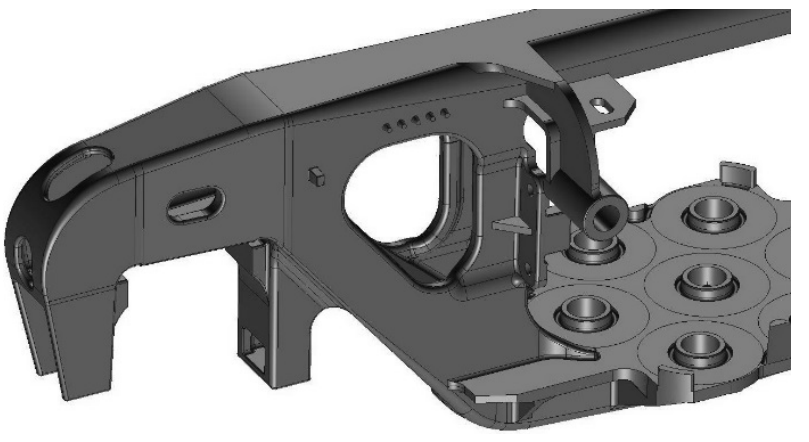

Fig. 5. Geometrical model of the bogie side frame with horizontal support surfaces

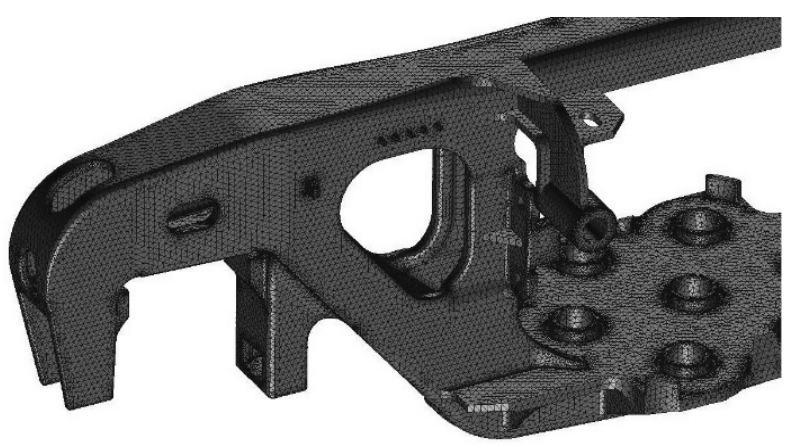

Fig. 6. Detail of finite element model of the bogie side frame with support surfaces
Comparison of stress distribution in the side frames was carried out under the action of vertical load only, which corresponded to the first variant of loading during the test $-490 \mathrm{kN}$ load, applied evenly to the spring support places of the central spring group, as this load contributes the major component into the stress-strain state of the side frame.

Comparison of stresses in the side frames is shown in Table 5.

Table 5

\section{Stresses in the side frame elements during the action of vertical load of $490 \mathrm{kN}$}

\begin{tabular}{l|c|c}
\hline \multirow{2}{*}{\multicolumn{1}{c|}{ Section }} & \multicolumn{2}{|c}{ Stresses in side frame, MPa } \\
\cline { 2 - 3 } & ZK-1 & analogue 18-100 \\
\hline $\begin{array}{l}\text { Interior angle } \\
\text { of pedestal } \\
\text { opening }\end{array}$ & 121 & 173 \\
$\begin{array}{l}\text { Process } \\
\text { window }\end{array}$ & 139 & 156 \\
$\begin{array}{l}\text { Lower angle } \\
\text { of central } \\
\text { spring opening }\end{array}$ & 245 & 225 \\
$\begin{array}{l}\text { Lower member } \\
\text { ound }\end{array}$ & 139 & 191
\end{tabular}

The presence of ramps in the section of transition from the inclined member to the upper member of the pedestal opening increased the cross-sectional area near the interior angle of the axle box opening, thus reducing the stress on this section. Also, it reduced stress in the area of process window and lower member, but increased their value in the lower angle of the central spring opening.

\section{Findings}

The strength evaluation of the three-piece bogie side frame when modelling loads during the field tests according to [7] does not consider in full the total load acting on the frame during its operation and provided for theoretical evaluation of the side frame strength [8].

The strength evaluation of the side frame by the results of field tests only does not give a complete picture of the distribution of stress fields, as the provided sensor installation points according to [7] do not cover most of the design elements with possible stress concentration. 
Application of the inclined support surfaces in axle box opening reduces stress in its interior angle.

\section{Originality and practical value}

The loads applied to the side frame during theoretical and experimental studies were compared to the loads acting during operation.

For the first time the impact of use of inclined surfaces in the pedestal box opening was evaluated.

The obtained results allow the more accurate assessment of the three-piece bogie side frame strength, as well as allow you to choose the more preferred method of side frame support in the axle box.

\section{Conclusions}

The documentation regulating the loads, which must be withstood by the side frames of freight car bogies, does not fully take into account the loads occurring during the car operation.

It is necessary to define more precisely the forces, acting in accordance with applicable regulatory documents, applied to the three-piece bogie side frame during the strength tests.

The strength evaluation of the side frame by the results of field tests only does not give a complete picture of the distribution of stress fields in the structure.

Inclined surfaces in axle box opening in the area of interior angle are more preferable than the horizontal ones.

\section{LIST OF REFERENCE LINKS}

1. Богатов, А. А. О повышении служебных характеристик боковой рамы тележки грузового вагона / А. А. Богатов, Р. А. Ильиных // Вестн. ВНИИЖТа. - 2010. - № 6. - С. 42-44.

2. Бороненко, Ю. П. Обобщение накопленного опыта проектирования тележек грузовых вагонов для создания их типоразмерного ряда / Ю. П. Бороненко, А. М. Орлова // Вісн. Дніпропетр. нац. ун-ту залізн. трансп. ім. акад. В. Лазаряна. - Дніпропетровськ, 2004. - Вип. 5. - С. 25-29.

3. ГОСТ 33211-2014. Вагоны грузовые. Требования к прочности и динамическим качествам. - Введ. 2015.11.01. - Москва : Стандартинформ, 2012. - 87 с.

4. Динамические качества грузовых вагонов, имеющих тележки с диагональными связями / Е. П. Блохин, К. Т. Алпысбаев, Р. Б. Грановский [и др.] // Вісн. Східноукр. нац. ун-ту ім. Володимира Даля. - 2012. № 5, ч. 1. - С. 12-16.

5. Захаров, С. М. Развитие тяжеловесного движения в мире / С. М. Захаров, К. П. Шенфельд // Вестн. ВНИИЖТа. - 2013. - № 4. - С. 9-18.

6. Мямлін, С. В. Прогнозування розвитку конструкції двовісного візка вантажного вагона / С. В. Мямлін, А. С. Мацюк // Вісн. Дніпропетр. нац. ун-ту залізн. трансп. ім. акад. В. Лазаряна. - Дніпропетровськ, 2009. - Вип. 27. - С. 24-29.

7. Надрессорные балки и боковые рамы литых двухосных тележек грузовых вагонов колеи 1520 мм. Методика статических испытаний на прочность. - Москва : ГосНИИВ : ВНИИЖТ, 1992.

8. Нормы для расчета и проектирования вагонов железных дорог МПС колеи 1520 мм (несамоходных) (с изменениями и дополнениями № 1 (с 01.02.2000 г.) и № 2 (с 01.03.2002 г.). - Москва : ГосНИИВ : ВНИИЖТ, 1996. - $352 \mathrm{c}$.

9. Определение параметров пространственного нагружения литых деталей тележки 18-9855 при проведении стендовых испытаний / Д. В. Шевченко, Т. С. Куклин, А. М. Орлова [и др.] / Техника железных дорог. - 2016. - № 1 (33). - С. 68-74.

10. ОСТ 32.183-2001. Тележки двухосные грузовых вагонов колеи 1520 мм. Детали литые. Рама боковая и балка надрессорная. Технические условия. - Введ. 2002.05.01. - Москва : МПС России, 2001. - 22 с.

11. Рейдемейстер, А. Г. Способы увеличения прочности боковых рам трехэлементных тележек / А. Г. Рейдемейстер, А. А. Шикунов // Наука та прогрес транспорту. - 2015. - № 5 (59). - С. 141-149. doi: $10.15802 / \mathrm{stp} 2015 / 55351$.

12. Ушкалов, В. Ф. Модернизация тележек грузовых вагонов как вариант обновления ходовых частей грузового подвижного состава / В. Ф. Ушкалов, А. Д. Лашко, Т. Ф. Мокрий // Вестн. ВНИИЖТа. - 2013. № 5. - C. 8-15.

13. Харыбин, И. А. Совершенствовать ходовую часть грузовых вагонов / И. А. Харыбин, А. М. Орлова, А. В. Додонов // Вагоны и вагонное хоз-во. - 2009. - № 1 (17). - С. 26-29.

14. Bubnov, V. Theoretical and experimental investigations of strength properties of cast parts for freight cars bogie with axle load of $245 \mathrm{kn} /$ V. Bubnov, S. Myamlin, N. Mankevych // TRANSBALTICA 2013 : Thesis of 
the 8th Intern. Conf. (09.05-10.05.2013) / Vilnius Gediminas Technchal University. - Vilnius, 2013. - P. 913.

15. Kure, G. The evolution of railway axlebox technology [Electronic resource] / G. Kure // Evolution. - 2010. - 7 December. - Available at: http://evolution.skf.com/the-evolution-of-railway-axlebox-technology/. - Title from the screen. - Accessed : 03.05.2016.

16. Kure, G. The evolution of railway axlebox technology - Part two: Present and future [Electronic resource] / G. Kure // Evolution. - 2011. - 9 March. - Available at: http://evolution.skf.com/the-evolution-of-railwayaxlebox-technology-\%E2\%80\%93-part-two-present-and-future/. - Title from the screen. - Accessed : 03.05.2016.

17. Myamlin, S. V. Experimental research of dynamic qualities of freight cars with bogies of different designs / S. V. Myamlin, O. O. Ten, L. O. Neduzha // Наука та прогрес транспорту. - 2014. - № 3 (51). C. 136-145. doi: 10.15802/stp2014/25921.

18. Rizvi, D. R. Optimisation of Bogie Springs for Higher Axle Load Wagons / D. R. Rizvi, P. K. Bharti // Intern. J. of Engineering Research \& Technology. - 2015. - Vol. 4. - Iss. 05. - P. 56-60. doi: 10.17577/ijertv4is050162.

\section{О. А. ШИКУНОВ ${ }^{1 *}$}

\footnotetext{
${ }^{1 *}$ Каф. «Вагони та вагонне господарство», Дніпропетровській національний університет залізничного транспорту імені академіка В. Лазаряна, вул. Лазаряна, 2, Дніпро, Україна, 49010, тел. +38 (056) 37315 04, ел. пошта tri_s@ua.fm, ORCID 0000-0002-8256-2634
}

\section{МІЦНІСТЬ БІЧНОЇ РАМИ ТРЬОХЕЛЕМЕНТНОГО ВІЗКА}

Мета. У науковій роботі передбачається оцінити вплив різних навантажень на напружено-деформований стан бічної рами візка вантажного вагона, а також розподіл полів напружень у конструкції бічної рами візка вантажного вагона, що спирається через горизонтальні поверхні, та через горизонтальні й похилі поверхні щелепного отвору. Методика. Розроблена об’ємна скінченно-елементна модель бічної рами візка ZK-1 вантажного вагона. До моделі прикладені сили відповідно до чинної нормативної документації на теоретичні дослідження, визначені напруження, що виникають в елементах моделі. Проведено статичні випробування бічної рами візка моделі ZK-1, при яких визначені напруження, що виникають у ключових точках рами при дії сил згідно з існуючою методикою статичних випробувань бічних рам візків вантажних вагонів. Для перевірки якості скінченно-елементної моделі визначена напруга в ній при дії сил, відповідних статичним випробуванням. Для узгодження напружень, отриманих при теоретичних дослідженнях, і статичних випробувань визначені відповідні коефіцієнти. Проведено порівняння результатів теоретичних та експериментальних досліджень напружень у конструкції бічної рами для ії небезпечних перетинів. Результати. Нормативна документація на проведення експериментальних досліджень міцності бічних рам не враховує повною мірою навантаження, що діють на раму під час іiі експлуатації, та передбачену теоретичним шляхом міцність бічних рам. Оцінка міцності бічних рам за результатами тільки натурних випробувань не дає повної картини розподілу полів напружень, бо передбачені місця встановлення датчиків не охоплюють більшості елементів конструкції, де можлива концентрація напружень. Наукова новизна. Автором проведено порівняння навантажень, що прикладаються до бічної рами при теоретичних та експериментальних дослідженнях, із навантаженнями, що діють в експлуатації. Визначена оцінка впливу застосування похилих поверхонь у буксових отворах. Практична значимість. Отримані результати дозволяють більш точно оцінювати міцність бічної рами трьохелементного візка, а також вибрати кращий спосіб спирання бічної рами в буксових вузлах.

Ключові слова: бічна рама; трьохелементний візок; міцність; випробування; розрахунок; спирання

\section{А. А. ШИКУНОВ ${ }^{1 *}$}

\footnotetext{
${ }^{1 *}$ Каф. «Вагоны и вагонное хозяйство», Днепропетровский национальный университет железнодорожного транспорта имени академика В. Лазаряна, ул. Лазаряна, 2, Днипро, Украина, 49010, тел. +38 (056) 3731504 эл. почта tri_s@ua.fm, ORCID 0000-0002-8256-2634
}

\section{ПРОЧНОСТЬ БОКОВОЙ РАМЫ ТРЕХЭЛЕМЕНТНОЙ ТЕЛЕЖКИ}


Цель. В научной работе предполагается оценить влияние различных нагрузок на напряженнодеформированное состояние боковой рамы тележки грузового вагона, а также распределение полей напряжений в конструкции боковой рамы тележки грузового вагона с опиранием через горизонтальные поверхности, и через горизонтальные и наклонные поверхности челюстного проема. Методика. Разработана объемная конечно-элементная модель боковой рамы тележки ZK-1 грузового вагона. К модели приложены силы согласно действующей нормативной документации на теоретические исследования, определены напряжения, возникающие в элементах модели. Проведены статические испытания боковой рамы тележки модели ZK-1, при которых определены напряжения, возникающие в ключевых точках рамы при действии сил согласно существующей методике статических испытаний боковых рам тележек грузового вагона. Для проверки качества конечно-элементной модели определены напряжения в ней при действии сил, соответствующих статическим испытаниям. Для согласования напряжений, полученных при теоретических исследованиях и статических испытаниях, определены соответствующие коэффициенты. Проведено сравнение результатов теоретических и экспериментальных исследований напряжений в конструкции боковой рамы для ее опасных сечений. Результаты. Нормативная документация на проведение экспериментальных исследований прочности боковых рам не учитывает в полной мере загрузки, действующие на раму во время ее эксплуатации, и предусмотренную теоретическим путем прочность боковой рамы. Оценка прочности боковой рамы по результатам только натурных испытаний не дает полной картины распределения полей напряжений, так как предусмотренные места установки датчиков не охватывают большинства элементов конструкции с возможной концентрацией напряжений. Научная новизна. Автором проведено сравнение нагрузок, прикладываемых к боковой раме при теоретических и экспериментальных исследованиях, с нагрузками, действующими в эксплуатации. Дана оценка влияния применения наклонных поверхностей в буксовом проеме. Практическая значимость. Полученные результаты позволяют более точно оценивать прочность боковой рамы трехэлементной тележки, а также возможность выбрать более предпочтительный способ опирания боковой рамы в буксовом узле.

Ключевые слова: боковая рама; трехэлементная тележка; прочность; испытания; расчет; опирание

\section{REFERENCES}

1. Bogatov, A. A., \& Ilinykh, R. A. (2010). O povyshenii sluzhebnykh kharakteristik bokovoy ramy telezhki gruzovogo vagona. Vestnik of the Railway Research Institute, 6, 42-44.

2. Boronenko, Y. P., \& Orlova, A. M. (2004). Generalisation of learned lessons in design of freight cars trucks for the creation of their standard series. Bulletin of Dnipropetrovsk National University of Railway Transport, 5, 25-29.

3. Vagony gruzovyye. Trebovaniya k prochnosti i dinamicheskim kachestvam, GOST 33211-2014 (2015).

4. Blokhin, Y. P., Alpysbaev, K. T., Granovskiy, R. B., Dzichkovskiy, Y. M., Krivchikov, A. Y., \& Fedorov, Y. F. (2012). Dinamicheskiye kachestva gruzovykh vagonov, imeyushchikh telezhki s diagonalnymi svyazyami. Visnik of the Volodymyr Dahl East Ukrainian National University, 5(1), 12-16.

5. Zakharov, S. M., \& Shenfeld, K. P. (2013). Global development of heavy-haul railway traffic. Vestnik of the Railway Research Institute, 4, 9-18.

6. Myamlin, S. V., \& Matsiuk, A. S. (2009). The prediction of the two-axles development of freight car truck. Bulletin of Dnipropetrovsk National University of Railway Transport, 27, 24-29.

7. GosNIIV, \& VNIIZhT. (1992). Nadressornyye balki i bokovyye ramy litykh dvukhosnykh telezhek gruzovykh vagonov kolei $1520 \mathrm{~mm}$. Metodika staticheskikh ispytaniy na prochnost. Moscow: GosNIIV, VNIIZhT.

8. GosNIIV, \& VNIIZhT (2002). Normy dlya rascheta i proektirovaniya vagonov zheleznykh dorog MPS kolei $1520 \mathrm{~mm}$ (nesamokhodnykh), Moscow: GosNIIV, VNIIZhT.

9. Shevchenko, D. V., Kuklin, T. S., Orlova, A. M., Savushkin, R. A., Dmitriev, S. V., \& Belyankin, A. V. (2016). Defining the parameters of the spatial loading carts cast parts 18-9855 during the bench tests. Tekhnika zheleznykh dorog, 1(33), 68-74.

10. Telezhki dvukhosnyye gruzovykh vagonov kolei $1520 \mathrm{~mm}$. Detali lityye. Rama bokovaya i balka nadressornaya. Tekhnicheskiye usloviya, OST 32.183-2001 (2001).

11. Reydemeyster, O. H., \& Shykunov, O. A. (2015). Strength increase methods of the side frame of the bogie in three-piece trucks. Science and Transport Progress, 5(59), 141-149. doi: 10.15802/stp2015/55351

12. Ushkalov, V. F., Lashko, A. D., \& Mokriy, T. F. (2013). Upgrading Freight Car Bogies as Possible Option of Freight Rolling Stock Running Gear Renovation. Vestnik of the Railway Research Institute, 5, 8-15.

13. Kharybin, I. A., Orlova, A. M., \& Dodonov, A. V. (2009). Sovershenstvovat khodovuyu chast gruzovykh vagonov. Vagony i vagonnoye khozyaystvo, 1(17), 26-29. 
14. Bubnov, V., Myamlin, S., \& Mankevych, N. (2013). Theoretical and experimental investigations of strength properties of cast parts for freight cars bogie with axle load of $245 \mathrm{kn}$. Thesis of the $8^{\text {th }}$ International Conference TRANSBALTICA 2013, May 09-10, 2013, Vilnius, 9-13.

15. Kure, G. (2010). The evolution of railway axlebox technology. Evolution. Retrieved from http://evolution.skf.com/the-evolution-of-railway-axlebox-technology/

16. Kure, G. (2011). The evolution of railway axlebox technology - Part two: Present and future. Evolution. Retrieved from http://evolution.skf.com/the-evolution-of-railway-axlebox-technology-\%E2\%80\%93-part-twopresent-and-future/

17. Myamlin, S. V., Ten, O. O., \& Neduzha, L. O. (2014). Experimental research of dynamic qualities of freight cars with bogies of different designs. Science and Transport Progress, 3(51), 136-145. doi: $10.15802 /$ stp2014/25921

18. Rizvi, D. R., \& Bharti, P. K. (2015). Optimisation of Bogie Springs for Higher Axle Load Wagons. International Journal of Engineering Research \& Technology, 4(05), 56-60. doi: 10.17577/ijertv4is050162.

Prof. I. E. Martynov, D. Sc. (Tech.), (Ukraine); Prof. S. V. Myamlin, D. Sc. (Tech.), (Ukraine) recommended this article to be published

Accessed: Oct. 12, 2016

Received: Jan. 04, 2017 